\title{
The Privilege of Confidential Communication Between Lawyer and Client
}

$\mathrm{T}$ HE profession of the law, for all the hard words laymen have said and say about it, is concededly an ancient and highly honorable calling. While the origins of medicine are to be found among mutterers of spells and hawkers of herbs, one class of experts in law in Western Europe were at all times-from the days of the Roman republic to our own-markedly gentlemen. These were the pleaders at the bar. In France they constituted a noblesse de la robe, only very little below the formal nobility and constantly seeping into it. In Scotland an advocate or a Writer to His Majesty's Signet might not unreasonably make bold, as said Master Alan Fairford in Redgauntlet, to hold up his head on a level with the noblesse of the sword or a wee bit above it. That was not quite the case in England; yet here, too, the upper reaches of the bar necessarily merged in the peerage, and the rawest of barristers was own brother to his Lordship on the bench.

Since some lawyers were gentlemen almost virtute officii, the common obligation of gentlemen not to betray a confidence reposed in them constituted, as Dean Wigmore has shown, the original basis of the protection accorded to communications between barrister and those who instructed him. ${ }^{1}$

As far as the attorney or the solicitor was concerned, we cannot say so much. The attorney was not a gentleman in most cases, was distinctly a man of business and for many centuries was very much the obedient servant of the family or person whose property he managed and whose affairs he directed. Yet if the pundonor was adequate to exempt an advocate or barrister from being asked questions touching his dignity, there was at least an equally old and powerful feeling that required a similar reticence on the part of attorney or solicitor. A servant must keep his master's secrets, and however honored and influential a servant, an attorney was for a long time definitely in that class and kept something of that standing, although, to be sure, he was never a "servant" in the specific sense which the English law attached to that term.

The duty of loyalty on the part of servants was an obvious and general one, based upon normal human feeling, and scarcely needed authority to establish it. But there was authority as well. It was one of the commonplaces of the Roman law that a servant-who

I 5 Wigmore on Evidence, 2 ed., $\$$ 2290-2291 (1923). 
was, to be sure, a slave-might not give testimony against his master. ${ }^{2}$ That was part of the inadmissibility in general of the testimonium domesticum, the testimony which worked against the strongest instincts of ancient society. The slave was incompetent as a witness, not so much because a master had the right not to be betrayed by his slave, but because a slave was essentially part of his family and the relationship of all members of the family was based on mutual fidelity. It seems that originally-as late perhaps as the middle of the second century A. D.-a slave might testify for his master, ${ }^{3}$ but shortly after that time, the rule was established that either for or against his master, his testimony was inadmissible. ${ }^{4}$ It was the same for parents and children, patrons and freedmen. ${ }^{5}$ There was, besides, a long list of persons who in criminal cases could not by the lex Iulia be compelled to give testimony, although apparently they might, if they so chose. ${ }^{\circ}$

Advocates equally from very ancient times could not be called as witnesses against their clients while the case was in progress. Cicero in prosecuting the Roman governor of Sicily regrets that he cannot summon the latter's patronus, Hortensius (Cic. in Verr. Act ii, 8,24 ), and the matter had received a statutory regulation in the Acilian law on bribery of 123 B. C.7 But just as in the case of the testimonium domesticum, this incapacity was extended afterward. By later imperial mandate, advocates and attorneys (agents) were made completely incompetent as witnesses in the case in which they acted. $^{8}$

Although the basis of the exclusion was the general moral duty not to violate the underlying fides on which the family was built, the rationalization of the rule was made to rest on the doctrine that the testimony was valueless either for or against a litigant. The theory seems to have been that if a member of a family testified in behalf of another-or an advocate on behalf of his client-he could not be believed because he had a strong motive for misstatement. If he

2 Buckland, W. W., The Roman Law of Slavery, pp. 88, et seq. (1908).

3 Buckland, W. W., loc. cit.; Tacitus, Ann. 3, 14, Papinian, citing a rescript of Hadrian, D. $48,18,17,2$.

4 D. 22, 3, 7 (Paul); C. 4, 20, 8 (294 A. D.).

5 C. $4,20,6$ (294 A. D.); C. $4,20,12$ (423 A. D.).

o D. 22, 5, 4 (Paul); Collatio, ix, 2, 3.

711. 32-36. Greenidge, The Legal Procedure in Cicero's Time, p. 484 (1901). The lex Acilia is found in all the Roman source books, Bruns, Girard, Riccobono, and is translated in Hardy, Roman Laws and Charters, p. 20 .

${ }^{8}$ D. $22,5,25$ (Arcadius, Charisius, 4th cent.). 
violated group solidarity by testifying against him, he was a disreputable person and unworthy of belief. ${ }^{9}$

That the Roman precedent was the origin of the English rule as far as attorneys are concerned, cannot be proved. It may have been, and it may have had some influence even on the barrister's obligation-although the conventional pundonor of gentlemen seems adequately to account for the latter. But from the eighteenth century on, the duty of loyalty conceived in terms of the attorney's duty to his employer, has overwhelmed the notion of the gentlemanbarrister's honor. It was not the lawyer's dignity but the client's interest that forbade disclosure of anything communicated between the two, and the inevitable inference was that since the client was the best judge of his interest, he might permit such a disclosure.

If we attempt to state the development from the attitude of the Roman law to that of our own, it may be stated about in this fashion. In the later Roman law the advocate had both the privilege of refusing testimony and the duty to refuse it. This privilege and duty were particular, "in personam," determinate, i. e. were relations to all the litigants in the particular case in which the advocate served or to all the persons concerned in the business the attorney had transacted. It was even more. By the Roman law of evidence, the testimony of a certain number of witnesses was sometimes formally essential to establish a case. The advocate's testimony-if it had been admitted-was void and the case remained unestablished. He was therefore under a "disability" to create the claims, etc., flowing from a decision in that cause. And since no act of his client could give him the right to testify, he was "immune" from having such a privilege conferred on him. ${ }^{10}$

At the common law the case has been different ever since the eighteenth century. The attorney or barrister still had the privilege and duty mentioned, but it was more sharply determinate than before and was related only to the person of his client. He was no longer "immune" from a waiver and he was therefore "liable" to having a privilege conferred upon him, or even a duty, if properly summoned. And since our theory of evidence is wholly different from the Roman theory, there can be no question of any disability.

Whether this relation of privilege, duty and liability between

${ }^{\circ}$ Licinius Rufus, D. 22, 5, 6.

$10 \mathrm{I}$ offer no apology for introducing the Hohfeldian terminology. In the illustration given it explains itself. The terms "determinate" and "determinable" for "in personam" and "in rem" I have set forth in an article appearing in the Italian Rivista di Filosofia del Diritto, VII, fasc, 2, p. 12 (1927). I hope at some future time to go into it more fully. 
attorney and client should continue to exist has been fiercely and violently debated. Our different set of social values has compelled us to discard the Roman attitude in the matter, which we have effectively done by permitting the testimony, at the instance of the client, and in the same way we have disposed of the medieval or semi-medieval theory of honor. In the absence of these factors, what is the best and worst that can be said about it as it stands?11

The best is the frequently asserted theory that public policy is involved. All persons ought to be able fully and freely to tell their lawyers all the facts, however remote, which surround the case, without fear that the lawyer's knowledge of these facts may be used to establish claims against them or subject them to penalties. It is part of the public policy against self-incrimination.

The worst that can be said of the duty-privilege under discussion, is that it seriously impedes the discovery of the truth, by withdrawing from possible testimony one who had the best opportunity for learning the truth. Public policy is equally concerned here, since there can be no more unquestioned public policy than that which seeks to settle disputed claims as they properly should be, and to prevent violation of penal laws.

At Rome the public policy which supported the privilege was not directed against self-incrimination, but against the corruption of the family - or quasi-family-relations which would ensue by making uncertain and suspicious what was assumed to demand the fullest confidence, uberrima fides. The policy which sought to conserve the uberrima fides was consciously deemed superior to that which sought the correct settlement of controversies or the punishment of offenders, with the one exception of treason.

Policy against policy, we certainly do not assess these things as the Romans did. There is no question in our accepted theory that truth is better than fides. We indicate that by the fact that we do

11 There is no fuller or better discussion of the subject of privileged communication between lawyer and client than in Dean Wigmore's treatise on evidence, 5 W'igmore on Evidence, 2 ed., $\S \S 2290-2329$ (1923). No summary of his arguments will do them justice, and I accordingly incorporate by reference his entire statement of the case for and against the privilege. The book is generally available. It is inconceivable that where there are lawyers there is no copy of Wigmore. Chi non ha Wiginor[o], non vada al foro.

Perhaps for the sake of fullness we may cite two other cases from Nottingham's ms. besides Rothwell v. King, quoted in Wigmore, op. cit., § $2298 \mathrm{n}$. These other cases are Spencer v. Luttrell and Stanhope v. Nott, cited in Parkhurst v. Lowten, 2 Swans. 194, 221, 36 Eng. Rep. R. 589, 599. In both of them, the great chancellor ordered discovery of a lease and $a$ deed, although the defendant pleaded he knew nothing of them but as counsel, and there was no question of an intended fraud. 
not exempt members of a family from testifying against each other, with the one exception of husband and wife. And those who most strongly support the accepted doctrine, do so with the full consciousness that it is an anomaly and must be strictly construed and not extended beyond the special situation for which it was created.

That the privilege-abstractly considered-is unpopular, may well be admitted. In fact, abstractly considered, it is quite indefensible. Bentham's denunciation cannot really be met as long as we keep on the level from which Bentham views the subject. ${ }^{12}$ But Dean Wigmore has correctly pointed out that it is the level of pure abstraction. And he has himself indicated that to be advantageously examined, it must be withdrawn into the realms of practical and humdrum affairs.

Dean Wigmore has added to the great many arguments advanced for and against the privilege a new one and given it vigorous support. The public policy involved is not primarily the general disinclination to encourage breaches of confidence, or the fundamental disapproval of self-incrimination, but the policy of discouraging litigation. Litigation is avoided if all facts are unreservedly placed before the legal adviser, and it is increased if the client cautiously avoids any statement except that which he thinks will support his cause.

It is a good argument and the better for being a homely and a practical one. Perhaps we can make it still homelier by concrete illustration.

John Doe enters the office of Samuel Parker for legal advice and assistance. Let us assume that Doe is a reputable business man, of honor and discretion, and that Parker is a capable and upright lawyer. Doe sets before his attorney the facts which constitute in his mind a grievance against Richard Roe, and he makes out a prima facie case. Under Parker's questioning - or through an innate garrulousness of his own-he mentions more and more circumstances, and several of these are fatal to his recovery. That fact is pointed out to him, he thanks his attorney, pays his consultation fee and Roe is left unsued.

Has litigation been avoided? Doe, ex hypothesi, wanted only his just claim. As soon as he is satisfied that he has none, he will not press an unjust one. Suppose he knew that Parker might testify to the facts which prevent his recovery. That certainly will not

12 Bentham's vigorous and picturesque attack upon it may be found in 5 Wigmore on Evidence, 2 ed., p. 17, $\$ 2291$ (1923), and in Professor Costigan's Cases on Legal Ethics, p. 82 (1917). The passage is found in full in Bowring's edition of Bentham, v. VII, pp. 473-475, Rationale of Judicial Evidence, b. IX, pt. IV, c. 5. 
deter him from communicating those facts, since he himself would testify to them. It can hardly be said that litigation has been prevented here by Parker's duty of non-disclosure.

But suppose Doe is a rascal. As soon as he knows what the facts are which prevent his recovery, he will either desire Parker to help him conceal them, or if Parker refuses the retainer, he will go to Messrs. Dodson \& Fogg who are less scrupulous. Now we may note that if this privilege exists, he may safely bring an action, but if it does not exist, he will run a certain risk in doing so. In other words, the privilege will in this case not lessen litigation, but increase it.

The net result, therefore, cannot be said to lend support to Dean Wigmore's contention, and it is submitted that the cases are not fanciful.

Of the older arguments advanced some are thin to the point of transparency. I may instance one, suggested in the earliest discussions and fully developed later. The privilege is declared to make men equal before the law.

"One great object of our legal system is that the rights of all persons shall be submitted with equal force to our courts of justice ... The weakness of the client finds a compensation in the lawyer's strength ... and thus every man's case is brought with nearly equal ability and chance of success under the consideration of the judge."13

Was there indeed once a condition in which all the King's Sergeants were equal in ability? The argument presupposes it. And if there ever was such a condition, will anyone maintain that it exists now and that clients come equally armed to the bar when one relies on the advice of, let us say, Mr. Elihu Root, and the other is represented by the last young person to slide through the mill of the bar examination?

I fear that neither the gown nor the laity is likely to be impressed by the argument of equality, and I doubt whether it would ever have been advanced, except for the urgent need felt for some sort of argument, good or bad.

The real fact is that, whether we admit it or not, the Roman and the medieval attitudes are very much in our bones. We, too, think that the relationships based on mutual fidelity are valuable constituents of our society and we do not relish the idea of disturbing them even to aid the processes of formal justice. And, although we are

${ }^{13}$ Anon. ("C") in the Law Magazine, XVII, 68 (1837), quoted in 5 Wigmore on Evidence, 2 ed., p. 15, $\$ 2291$. Dean Wigmore ( $\$ 2291$, note) regards this as nearly the best treatment of the topic. 
conscious of lay derision, we still think of the fraternity of the law as a noblesse of the robe, who are bound by a pundonor and have no few conventional duties that are not without their influence in facilitating and smoothing the social functions in which they intervene.

On the criminal side there is, besides, a healthy and commendable repugnance to self-incrimination. The term can be made a fetish and has been made one, and as an idol-decidedly idolum fori-it has done unquestionable mischief and has encouraged those police abuses which are far too much condoned by the respectable portion of our society. ${ }^{14}$ To warn a man that what he will say will be used against him, when we have every intention of using against him what he has said or done, does not sound sensible. Yet in a modified form the rule has its value. We should not like to convict a man solely on what he has himself been trapped into admitting, and when he speaks by the mouth of an advocate, our feeling is quite the same.

But self-incrimination deals only with criminal cases. Criminal cases are only a small part of the law and even here there are few after all in which an attorney's testimony would be of much assistance in convicting or in acquitting an accused person. It may indeed be said that for civil as well as criminal cases the whole question of the privilege is of decreasing importance. Even if it did not exist, we cannot suppose that a litigant would often summon the attorney for the opposite side, in order to establish his case. That will happen, from the nature of the situation, far more rarely than the instance in which the opposite party is called-and that is quite uncommon.

Prehaps the following suggestion deserves consideration. The so-called privilege is - as is generally the case with traditional termsnot a single but a complex relation. It is both a privilege proper, i. e., in refusing disclosure, the lawyer is violating no one's right;-but it is also a duty, that is, he owes to his client the duty to refuse. Suppose the duty were abolished. That would bring us back to the situation of the seventeenth century-the pundonor of the barrister, the quasi-familial duty of the attorney-agent, influenced perhaps by the Roman notion of fides or the Roman rationalization of that fides. In that case, an attorney questioned as to such communication would be protected by his privilege-his and not his client's-if he chose to use it.

What would be the result in practice? It would mean that in

14 $\mathrm{Cf}$. on self-incrimination a recent article of Dean Frank Irvine, "The Third Degree and the Privilege Against Self-Crimination," 13 Cornell L. Q. 211 (1928). 
most instances, communications between reputable clients and reputable attorneys would be quite as fully protected as they are now. Communication by disreputable clients might suffer. We may cry with Bentham-so much the better! Our real difficulty would be with the disreputable attorney of a reputable client, who might conceivably use his repossession of an ancient privilege as a means of blackmail.

I do not conceive that this is an urgent or pressing danger. Disreputable attorneys have a way of becoming known to their brethren, long before the public knows of them. A fully organized bar may well be trusted to deal with such rascals with less tenderness than a lay jury would, if the situation arose.

A recent inroad into the privilege has been advanced in the proposed rule of the California State Bar Association-still under advisement in the Supreme Court-Rule No. $18 .{ }^{15}$ It must be considered in the light of the history and the analysis of the privilege itself.

It does not, it will be noted, affect the duty-privilege as a whole, but only to a limited degree-as to those matters which arise during the progress of litigation. But on this point it makes a drastic change. It does not merely abolish the duty of non-disclosure, leaving the ancient privilege, but it adds an affirmative duty of disclosurea determinable duty toward all members of the profession and enforceable at the instance and through the instrumentality of the State Bar.

The State Bar Act ${ }^{16}$ which empowers the Board of Governors of the Bar to "formulate and enforce rules of professional conduct" does not in terms repeal any section of the Codes or other existing laws. It nay, therefore, be a question whether the duty of the attorney to keep the secrets of his clientr and the incapacity of the.

15 "If a member of the State Bar learns, during the progress of litigation in which he is engaged, that his client intends to engage directly or indirectly in misconduct in reference thereto, he shall use his utmost endeavor to prevent such misconduct; if he learns, during such litigation, that a witness called by him has wilfully testified falsely, he shall, if possible, give such witness a reasonable opportunity to retract such false testimony; if the client persists in such misconduct, or if such witness does not retract such false testimony, or if the attorney learns that the client has been guilty of misconduct in reference to such litigation, he shall promptly disclose the facts to the judge or judicial officer before whom such litigation is pending. Such disclosure does not violate the obligation of the attorney to maintain iuviolate the confidence or to preserve the secrets of his client." The State Bar Journal, Apr. 1928, p. 205.

${ }_{16}$ Cal. Stats. 1927, p. 38 ; see particularly c. $34, \S 25$, p. 41.

17 Cal. Code Civ. Proc. \& $282(5)$.

Section 282 is derived from the oath of the attorneys at Geneva, but sub- 
attorney to testify to any communication made to him by his client without his client's consent ${ }^{18}$ are by implication subject to the modification which this rule of professional conduct involves. To be sure, the penalty announced by the Board of Governors is professional only, but it would be a curious result if a person could not testify to something which he is required under threat of discipline to disclose of his own accord to the court. Is it an advisable change? The answer must depend largely on personal feeling. Perhaps we can be aided by considering existing situations.

What will a reputable lawyer do now under the supposed emergency? The answer cannot be doubtful. He will withdraw from the case at once. The threat of such a withdrawal will in most cases be sufficient. If it will not, we may be sure that the dishonest client will of his own accord dismiss his attorney before-and not afterhe consummates the practice referred to, and provide himself with more pliant counsel, if he can get it.

And, in that case, are we to suppose that the dishonest lawyer will take the affirmative duty imposed upon him seriously? What risk does he run, if he does not? He can be proved to have violated the rule only by the testimony of his accomplice, which is not likcly to be offered because of the personal risk-and which as far as subornation of perjury is concerned cannot be offered.

We may say consequently that in the only cases in which it is worth while to enforce such a rule, it will be excessively difficult, if not impossible, to enforce it.

It is doubtful whether our national experience encourages us to believe that the creation of duties which are not likely to be enforced, appreciably raises the general moral tone of communities, large or small. Perhaps we shall do better if we leave the matter to professional honor, controlled as it would be by a concretely embodied professional opinion. A sense of professional honor has not altogether prevented successful rascalities from being perpetrated, but it has done something in that direction. It may do more than this quasi-penal sanction can do, as may be seen in the experience of

section 5 was not a part of that oath, as can be seen from any annotated edition of the Code of Civil Procedure. The famous oath is still in use at Geneva, being $\S 129$ of the law of Oct. 13, 1920, Loi sur L'Organisation Judiciaire, as I am informed by a kind communication of Professor de Claparède of the University of Geneva (Oct. 15, 1927). That there is no oath to secrecy is probably due to the fact that in Geneva, violation of a professional secret has long been a penal offense and needed no other sanction.

18 Cal. Code Civ. Proc., \$1881(2). 
countries in which a full penal sanction has been attached to the violation of professional secrets.

On the Continent the question of confidential communication between an attorney and his client has engaged the attention of many writers. There are very few decisions on the subject either in France or Germany, although it is admitted that violations of confidence-greater and smaller-are not of infrequent occurrence. On the other hand, writers on law, who play-it need hardly be stateda far larger role in the Continental system than in ours, have discussed the matter with great fullness and there have been vigorous controversies about it.

Both in Germany and France the matter is regulated by the Penal Code. In France it is Art. 378 of the Code Penal, in Germany, Art. 300 of the Strafgesetzbuch, which makes the violation of a professional secret on the part of lawyers and physicians, a crime punishable by fine and imprisonment. This is obviously a far more drastic sanction than the purely civil duties and privileges and incapacities which are all that the Roman law or the Anglo-American law created.

In France the weight of authority-which is in this case doctrinal discussion-is that there is no exception to the rule. ${ }^{10}$ Even a lawyer on the witness stand may not answer a question involving a breach of his duty and the fact that he was a witness would be no defense to a prosecution. ${ }^{20}$ It may be noted that besides the criminal prosecution, there would be in France ipso facto, a partie civile, i. e. the injured party can always recover the damages caused by an act declared criminal in a proceeding carried on simultaneously with the prosecution itself.

In other words, advocates are completely incompetent as witnesses in a case affecting their client, just as they were at Rome,- -an incapacity which they share, again as in Rome, with the members of the litigant's family.

In Germany, however, the Code makes penal only an "unauthorized" disclosure,- "unbefugt". The discussion of what the term involves has busied men no less eminent than Jellinek, Mittermaier,

19 Werner, Le Secret Professionel, pp. 64 et seq. (Geneva, 1907).

20 This was the decision of the Cour de Cassation in a criminal case reported in Dalloz, D. P. 99. 1. 585., and is undoubtedly in accord with the weight of judicial and doctrinal authority, as can be seen by the note of M. Marcel Planiol to that case. A full discussion by the court of the possible limitation on the doctrine may be found in a case decided in Rennes in 1903, D. P. 1905. 2. 321., to which an admirably full examination of the whole question is appended. Whether the client may free the attorney from his obligation is a subject of lively dispute. 
von Dohna ${ }^{21}$ and many others. The consensus of opinion is to the effect that disclosure on the witness stand is not "unauthorized." This puts the question on an altogether different footing from that of French law and our own. Private breach of professional confidence becomes a crime, and doubtless, as a matter of course, subjects an attorney to discipline. But the determinable duty of no disclosure is qualified by a determinate duty of disclosure to the court upon interrogation. There is, however, not even in this system any duty of voluntary disclosure which rests upon an attorney.

The topic has given occasion for a certain amount of jurisprudential analysis. Jellinek sought to find the basis of the professional privilege in an implied contract between attorney and client. This has met with very little acceptance. The tendency is to see in it a duty created by statute, and those who maintain that the duty ceases when the attorney is on the witness stand, use this circumstance as an illustration of the favorite theory of conflict of legal duties-the duty to the client and to the State of secrecy, colliding with a still higher duty of the attorney to the State not to withhold what the State through its duly selected ministers has need of knowing. ${ }^{22}$

In the last analysis, the considerations just mentioned, although stated more abstractly than we choose to do, is nothing more or less than a discussion of the policy of the rule. The reasons for or against it are the same as in any system. There is a general feeling that the French absolute ineapacity is unfortunate and that some modification is desirable.

Berkeley, California.

Max Radin.

21 Jellinek, Der Umfang der Verschwiegenheitspflicht des Artzes und des Anwalts; Monatsschrift für Kriminalpsychologie, v. III, Dp. 672 et seq. (1907).

Mittermaier, Gutachten über Sec. 300 Reichsstrafgesetzbuch; Zeitschrift für die ges; Strafrechtswissenchaft, v. XXI, pp. 221 et seq.

Graf von Dohm, Die Rechtswidrigkeit, pp. 32 et seq. (1905).

22 Früh, Paul, Die strafbaren Pflichtverletzungen des Rechtsanwalts gegenüber seinem Klienten, pp. 106 et seq. (Diss Zürich, 1910). Lübke, Carl, Die Schweigepflicht der Rechtsanwälte (Diss. Jena, 1920) is neither so full nor so accurate. 